\title{
Biocompatibility of EDTA, EGTA and Citric Acid
}

\author{
Simone Maria Galvão de SOUSA ${ }^{1}$ \\ Clovis Monteiro BRAMANTE2 \\ Eulázio Mikio TAGA ${ }^{3}$ \\ ${ }^{1}$ Department of Materials Science and Metallurgy, Pontifical Catholic University of Rio de Janeiro - PUC-Rio, \\ Rio de Janeiro, RJ, Brazil \\ Departments of ${ }^{2}$ Endodontics and ${ }^{3}$ Biochemistry, Faculty of Dentistry of Bauru, University of São Paulo, \\ Bauru, SP, Brazil
}

\begin{abstract}
This in vivo study evaluated, through the physicochemical assay method for quantification of enhanced vascular permeability, the irritating potential of EDTA, EGTA, citric acid and saline. Thirty-two male Wister rats were anesthetized and four experimental sites were demarcated on their backs. Injections of $2 \%$ Evans blue $(20 \mathrm{mg} / \mathrm{kg})$ were administered intravenously into the lateral caudal vein. The test solutions were immediately injected intradermally $(0.01 \mathrm{~mL})$ into the experimental sites. The animals were killed 30 min, 1 , 3 and $6 \mathrm{~h}$ after injection of the solutions and each piece of skin was submerged in formamide and incubated at $45^{\circ} \mathrm{C}$ for $72 \mathrm{~h}$. After filtration, the optical density was measured in a spectrophotometer and the total amount of dye extracted from the samples was calculated by means of a standard calibration curve. Data were analyzed statistically by two-way ANOVA and Tukey's HSD test. Compared to control, EDTA had the greatest volume of dye followed by EGTA and citric acid, for all time periods. There were statistically significant differences between all solutions $(\mathrm{p}<0.01)$. Considering the periods assessed, a significant difference was observed between the 3- and 6-h groups ( $\mathrm{p}<0.05$ ), but not between the 30-min and 1-h groups. Among the organic acids evaluated in this study, citric acid yielded the lowest amount of extracted dye. This indicates that the citric acid was the least irritating solution.
\end{abstract}

Key Words: biocompatibility, citric acid, EDTA, EGTA, root canal therapy.

\section{INTRODUCTION}

Biomechanical preparation of the root canal system is an important step in successful endodontic therapy. This phase is regarded as complex because it associates physicomechanical and chemical phenomena with the operator's ability. Torneck (1) reported that the tissue reaction to root canal irrigants used clinically is influenced by: a) type, concentration, and physical form of the agent utilized; b) amount or volume of the agent used; c) manner through which the agent is placed and sealed into the root canal; d) size of the apical foramen; e) histological status of the periodontium; f) time of tissue exposure to the agent, and g) patient's susceptibility to injury.

Chelating agents and organic acids provide both good physicochemical characteristics and biological compatibility. Their biocompatibility has been exam- ined through a variety of methods and different levels of inflammatory reactions have been reported (2-7). Recommendations for use have been based more on clinical observations and physicochemical properties than on biological aspects.

Patterson (8) investigated the tissue reaction to intramuscular injections of different EDTA concentrations $(0.03,0.1,0.3,1,3$ and $10 \%)$, and observed that the inflammation seemed to increase as the percentage of the EDTA increased. However, the degree of inflammation was only moderate in the $10 \%$ EDTA group.

Silveira et al. (5) studied the irritating potential of $15 \%$ EDTA (pH 7.3) and 15\% EDTAC (pH 7.3) solutions using the vital dye exudation technique complemented by histopathological analysis. Small amounts $(0.1 \mathrm{~mL})$ of each substance were inoculated into the connective tissue of rats, which were immediately injected endovenously with $2 \%$ Evans blue dye. 
Three hours later, the animals were killed and the inflamed areas were sectioned. The dye was recovered from samples of the 24 rats and assessed using a spectrophotometer. With both methods of evaluation, EDTA and EDTAC showed severe irritation at the concentrations employed. These results are in agreement with those of Rutberg et al. (4), who reported that EDTAC is a very irritating agent.

Other in vivo experimental studies also reported that EDTA has severe tissue irritating properties $(6,7)$. Segura et al. (6) evaluated the effect of EDTA and EGTA on vasoactive intestinal peptide binding to macrophage membranes. EGTA was four times less potent than EDTA in inhibiting specific vasoactive intestinal peptide binding to macrophage membranes. In addition, Segura et al. (7) studied the effect of EDTA on substrate adherence capacity of inflammatory macrophages to determine whether EDTA leakage during root canal preparation could modulate the function of such cells (phagocytosis process), altering the periapical inflammatory reactions. Their results demonstrated that EDTA inhibited the substrate adherence capacity of macrophages in all conditions tested and this effect was both time- and dose-dependent. However, when calcium chloride was added to the incubation medium together with EDTA, the inhibitory effect of this acid on adherence rate decreased. The ability of local calcium application to inhibit the effect of EDTA was also studied on rat skin capillary permeability and mediator actions (9).

A number of studies have demonstrated the biocompatibility of citric acid in operative dentistry and periodontology $(3,10-13)$. This biological organic acid also presents favorable physicochemical characteristics $(14,15)$, as well as a positive antimicrobial capacity (16).

The method described by Udaka et al. (17) has often been employed to quantify the irritating potential of a number of substances injected intradermally. This simple method analyzes physicochemically the plasmatic exudate produced after an increase of vascular permeability due to the irritating potential of test solutions. The method is useful not only to quantify the inflammatory exudate elicited by phlogistic agents, but also to evaluate the efficacy of anti-inflammatory drugs $(9,18)$. This model has been successfully used in previous studies to assess the irritating potential of a variety of endodontic drugs $(4,5)$. Nagem-Filho and Pereira
(19) suggested a complementary analysis of this method on the basis of the correlation between absorbency values and irritating potential.

In endodontic practice, more effective irrigants with low irritating potential are desirable. The purpose of this study was to evaluate the irritating potential of EDTA, EGTA, citric acid and saline (control) at 4 different time periods using the physicochemical assay method for quantification of enhanced vascular permeability (Evans blue test).

\section{MATERIAL AND METHODS}

The test solutions utilized were: $15 \%$ EDTA, $\mathrm{pH}$ 7.4 (ethylenediaminetetraacetic acid; Merck KGaA, Darmstadt, Germany); 15\% EGTA, pH 7.4 (ethyleneglycol-bis(oxyethylenenitrilo)-tetraacetic acid; Sigma, St. Louis, MO, USA); 15\% citric acid, pH 1.0 (Merck) and saline (control; Merck). The tested acid solutions were freshly prepared at the Laboratory of Biochemistry of the School of Dentistry of Bauru, University of São Paulo. The salts were weighed and diluted in deionized water, and $\mathrm{pH}$ was adjusted ( $\mathrm{pH}$ meter B371, Micronal, São Paulo, SP, Brazil).

Thirty-two adult male Wistar rats (Rattus novergicus), weighing approximately $350 \mathrm{~g}$, were used. They were anesthetized with sulfuric ether (Synth, Labsynth Produtos de Laboratório Ltda, Diadema, SP, Brazil), their backs were shaved and 4 experimental sites were demarcated. Their tails were washed and dried to facilitate the injections of $2 \%$ Evans blue (20 $\mathrm{mg} / \mathrm{kg}$; Merck) administered intravenously into the lateral caudal vein. Immediately afterwards, $0.1 \mathrm{~mL}$ of the test solutions were injected intradermally into the experimental sites following a rotation system. The animals were assigned to 4 groups according to the time period tested. The animals were killed $30 \mathrm{~min}, 1,3$ and $6 \mathrm{~h}$ after injection of the solutions. The dorsal skin was dissected away and skin lesions were punched out with a standard steel punch (3-cm diameter). Each piece of skin containing the lesion was cut into small fragments and the dye was extracted upon immersion in $10 \mathrm{~mL}$ formamide (Mallinckrodt Chemical, Phillipsburg, NJ, USA) for $72 \mathrm{~h}$ at $45^{\circ} \mathrm{C}$. After filtration with glass filter, the optical density was measured at $620 \mu \mathrm{m}$ in a spectrophotometer (Ultrospec 2000, Pharmacia Biotech, Cambridge, England, UK). In the EDTA group, 1:10 dilutions were necessary in 31 of the 32 samples, as 
well as in 15 of the 32 samples in the EGTA group. In the citric acid and saline groups, sample dilutions were not necessary. The total amount of dye extracted from the samples was calculated by means of a standard calibration curve. Data were analyzed statistically by two-way ANOVA and Tukey's HSD test.

\section{RESULTS}

Table 1 shows the means and standard deviations of the amount of dye extracted $(\mu \mathrm{g})$ in the control and experimental groups. Compared to saline (control $139.55 \mu \mathrm{g})$, EDTA $(1447.33 \mu \mathrm{g})$ was the most irritating solution followed by EGTA $(770.59 \mu \mathrm{g})$ and citric acid (329.81 $\mu \mathrm{g}$ ), for all four periods evaluated. Tukey's HSD test showed statistically significant differences ( $p<0.01)$ among the tested solutions. However, considering the time period, a significant difference $(\mathrm{p}<0.05)$ was observed between the 3 -h and 6 -h groups, but not between the 30-min and 1-h groups. Figure 1 illustrates the means of dye extracted from all 4 groups, showing an enhanced vascular permeability at the 6-h experimental time. Although a statistically significant difference was seen between citric acid and saline, the means of dye extracted in these groups were numerically close to each other. This is even more evident when the means of dye extracted in the other groups are considered. Furthermore, the variability of data in the EGTA group was greater than that in the other groups, the former showing a decrease in the amount of dye extracted after $30 \mathrm{~min}$ and an increase at $6 \mathrm{~h}$ (Fig. 1). Analyzing the means of all groups and considering their standard deviation, these results indicated that all solutions yielded a continuous irritating potential even after $6 \mathrm{~h}$.

\section{DISCUSSION}

The irrigation phase plays an important role

Table 1. Means $(\mu \mathrm{g})$ and standard deviations $( \pm \mathrm{SD})$ of the total amount of dye extracted in the control and experimental groups.

\begin{tabular}{lcccc}
\hline Time & EDTA & EGTA & Citric Acid & Saline \\
\hline $30 \mathrm{~min}$ & $1281.03 \pm 515.07$ & $826.21 \pm 170.29$ & $280.92 \pm 140.84$ & $153.93 \pm 47.15$ \\
$1 \mathrm{~h}$ & $1384.65 \pm 329.40$ & $714.60 \pm 254.91$ & $271.41 \pm 135.09$ & $115.68 \pm 48.57$ \\
$3 \mathrm{~h}$ & $1394.75 \pm 234.56$ & $580.63 \pm 291.76$ & $286.43 \pm 102.08$ & $115.36 \pm 58.60$ \\
$6 \mathrm{~h}$ & $1728.90 \pm 433.09$ & $960.92 \pm 557.17$ & $480.50 \pm 212.34$ & $173.23 \pm 51.31$ \\
\hline
\end{tabular}

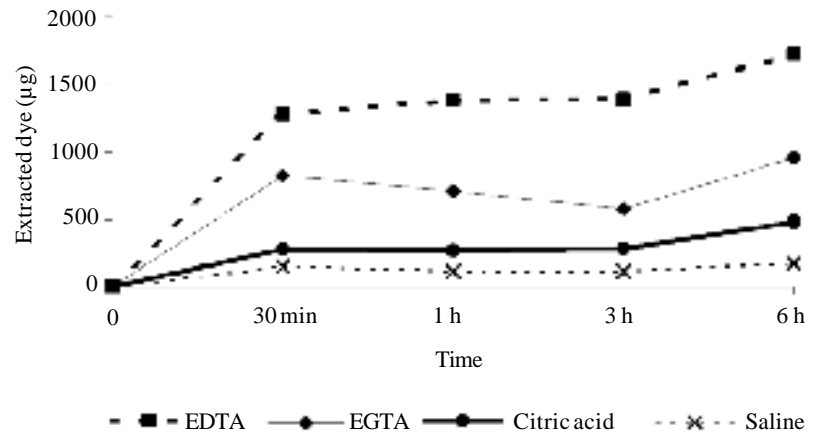

Figure 1. Variation in the amount of dye extracted $(\mu \mathrm{g})$ in the groups, as a function of time.

during endodontic therapy. The choice of an adequate irrigating solution must always consider its biocompatibility with respect to biological aspects. Chemical injury occurs when a vital tissue is exposed to solutions that are not compatible with cellular metabolism. Injury may vary from mild to severe, i.e., from an alteration in the metabolism and function of the cell up to complete cessation of all cellular activity, culminating in cellular death. Phlogistic agents induce organic lesions, which cause vasodilatation and an increase in vascular permeability to plasma and leukocytes.

The acute inflammatory effect of acids was observed in the inflammatory model obtained by subcutaneous injection. In the vascular permeability assay, the amount of protein-bound dye leaked into the inflamed area is an indicator of the severity of the inflammation. The inflammatory effect of the acids was investigated in both immediate (30-min and 1-h) and late (3-h and 6h) phases of vascular permeability. Under physiological conditions, there is a free movement of fluids and electrolytes across the wall of the terminal vascular bed, but not of plasmatic proteins. The equilibrium is maintained by a balance between effective hydrostatic pressure in the capillary bed, which tends to drive the fluid out of the vascular system, and the restraining effect of the equal and opposite osmotic pressure of the plasma proteins. In inflammation, vascular permeability is increased, causing an imbalance in the pressure relationships. Fluids, electrolytes and proteins escape in high amounts through the vascular 
endothelium and are collected in the intercellular space to induce the inflammatory edema. The most widely employed method to measure the rate of edema is based on the leakage of protein-bound dye into the inflamed area. Some vital dyes, such as Evans blue, when administered intravenously, interact with the basic nitrogen of plasmatic albumin and are suitable as plasmatic markers for detecting leakage of proteins into a site of inflammation.

The most relevant in vivo test is that in which the experimental condition can be clinically representative. The model used in the present study is a modification of that postulated by Udaka et al. (17) and it is similar to that employed by Silveira et al. (5) and Catanzaro-Guimarães et al. (18). This protocol is simple and straightforward to perform. Another advantage is that it allows for a rapid primary screen to evaluate the inflammatory potential of a variety of root canal medicaments, including chelating agents. Nevertheless, this method may not provide an accurate representation of the irritating potential of the test solutions when they cause extensive damage. This destruction occurs because the thin tissue around the test site easily deteriorates along with its diffusion. In addition, attention must be given to the site and direction of injection. Sometimes, the size of the external blue zone does not correspond to the size of the lesion in the underlying connective tissue when freely dissected (4). This study used a subcutaneous injection technique in order to simulate the extrusion (overflow) of solutions through the root apex.

Apical extrusion of chelating solutions or acids may alter some local physiological processes. EDTA, EGTA and citric acid can chelate a number of metallic ions such as magnesium, manganese, iron, copper, zinc, calcium, and other divalent cations, which are considered co-factors to several enzymatic reactions (20). Calcium ions participate mainly in blood coagulation, neuromuscular contraction and vascular permeability. Nearly half of these ions link to proteins, especially albumin, whereas the other half is ionized. Considering the acid chelating effect on calcium ions, one can understand the magnitude of the injuries that these substances may cause on the periapical region.

The findings of this study revealed an increase in the range of dye values in the 6-h period (late phase of vascular permeability). It is likely that the extracellular local defense processes were unable to completely neutralize the tested acids during the longer evaluation period. For this reason, the blood system reacted with an increase in vascular permeability and inflammatory exudate with the aim of diluting those injurious agents. EDTA and EGTA showed the highest means at this period compared to the other groups. This may possibly be ascribed to the difficulty of the host defense mechanisms to remove the chelating complexes elicited by the reaction between these acids and the local divalent ions.

The results of this study are in agreement with those reported by Rutberg et al. (4) and Silveira et al. (5), who showed EDTA solutions to be aggressive on tissues, with evidence of intense exudation and hemorrhagic areas. These authors suggested that the extravasated red blood cells could possibly be due to the effect of EDTA on important metabolites $\left(\mathrm{Ca}^{++}\right.$and $\left.\mathrm{Mg}^{++}\right)$in body homeostasis. This reaction can interfere with cell wall integrity, intercellular binding and coagulation, which are calcium-dependent mechanisms. The interaction between EDTA, calcium and mediators (histamine, bradykinin and serotonin) was well reported by Busch et al. (9), showing the importance of calcium ions on capillary permeability. The depletion of extracellular $\mathrm{Ca}^{++}$induced a reversible opening of the junctions, with retraction of cellular microfilaments and increased monolayer permeability. In addition, the effect of EDTA was reversed by the addition of calcium.

In this study, hemorrhagic areas were present in both EDTA and EGTA groups, though more frequently observed in the EDTA group with no correlation with time. Dilutions of the samples were required in both groups, mainly in the EDTA group. Studies pointing out the satisfactory tolerance to EDTA solutions have applied different methodologies and analyzed their results at 24, 48 and $96 \mathrm{~h}$, suggesting a decrease in the inflammatory response when EDTA is used $(2,8)$. The evaluation periods used in these studies were considerably longer than those established in the present investigation. Segura et al. (6) also demonstrated that EDTA is more aggressive than EGTA, which is probably due to differences in the ions' affinity and reaction velocity.

The interaction between chelating agents, $\mathrm{Ca}^{++}$ and macrophage membranes has been demonstrated $(6,7)$. Taking into account that macrophages play an essential role in inflammatory reactions and the immune response, the apical extrusion of EDTA or EGTA during endodontic therapy could modify the apical inflammatory response. The substrate adherence ca- 
pacity of monocytes requires the presence of calcium. Therefore, the proper use of these substances should be highlighted because adhesion is the initial process to phagocytosis and further to antigen presentation by macrophages. It is clear that EDTA and EGTA findings cannot currently be extrapolated to citric acid. Perhaps different results were recorded because citric acid is a biological acid. Applying the criteria suggested by Nagem-Filho and Pereira (19), EDTA and EGTA yielded a severe irritating potential, while citric acid and saline presented a moderate and low irritating potential, respectively.

Based on the results of the present investigation, it may be inferred that, with no exceptions, all acid solutions should be used in a safe way, respecting the periapical tissues. It should be mentioned that, even though the inflammatory reaction takes part in the healing process, it cannot be severe, otherwise it would interfere with this process, i.e., affect all cellular activity. This study has attempted to contribute to the development of new substances that are less irritating to vital tissues. It is well known that a solution that combines high antimicrobial activity, optimal tissue compatibility and ability to remove smear layer is very difficult to obtain. The results of this research indicated that citric acid could be useful as an alternative irrigating solution to EDTA in endodontic therapy. Nevertheless, further investigation must be carried out to assess its other properties and actions.

\section{RESUMO}

Este estudo in vivo avaliou o potencial irritativo do EDTA, EGTA, ácido cítrico e soro fisiológico (controle) durante a fase exsudativa do processo inflamatório. Aplicou-se, intravenosamente na veia caudal lateral de 32 ratos machos da linhagem "Wistar", variação albina, $20 \mathrm{mg} / \mathrm{kg}$ de azul de Evans $2 \%$. Em seguida, no tecido subcutâneo da região dorsal dos animais injetou-se $0,01 \mathrm{~mL}$ das soluções testes. Após os intervalos de $1 / 2,1,3$ e 6 horas, os animais foram sacrificados, suas peles dorsais foram excisadas e submetidas à análise do corante extravasado pela espectrofotometria de absorção de luz. Os dados obtidos foram avaliados pela análise de variância a 2 critérios e teste de Tukey. Em todos os períodos de tempo estudados, os maiores valores de corante extravasado foram observados no grupo do EDTA seguido pelos grupos do EGTA e ácido cítrico, em comparação ao grupo controle. Houve diferença estatisticamente significante entre todas as soluções testadas $(\mathrm{p}<0.01)$. Quando considerado o fator tempo, notou-se diferença significante entre os grupos de 3 e 6 horas $(\mathrm{p}<0.05)$. Entretanto, não houve diferença entre os grupos de tempo de $1 / 2$ e 1 hora.
Dentre os ácidos orgânicos avaliados, os resultados demonstraram que o ácido cítrico apresentou o menor potencial irritativo.

\section{ACKNOWLEDGEMENTS}

The authors thank Ovídio dos Santos Sobrinho and Thelma Lopes Silva for their technical assistance.

\section{REFERENCES}

1. Torneck CD. Reaction of hamster tissue to drugs used in sterilization of the root canal. Oral Surg Oral Med Oral Pathol 1961; 14:730-747

2. Nygaard-Östby B. Chelation in root canal therapy. Ethylenediamine tetraacetic acid for cleansing and widening of root canals. Odont Tidsk 1957;65:3-11.

3. Loel DA. Use of acid cleanser in endodontic therapy. J Am Dent Assoc 1975;90:148-151.

4. Rutberg M, Spangberg E, Spangberg L. Evaluation of enhanced vascular permeability of endodontic medicaments in vivo. $\mathrm{J}$ Endod 1977;3:337-351.

5. Silveira NL, Tavares T, Soares IJ. Potencial irritativo de soluções à base de EDTA. Rev Assoc Paul Cirurg Dent 1994;48:14891493.

6. Segura JJ, Calvo JR, Guerrero JM, Sampedro C, Jimenez A, Llamas R. The disodium salt of EDTA inhibits the binding of vasoactive intestinal peptide to macrophage membranes: endodontic implications. J Endod 1996;22:337-340.

7. Segura JJ, Calvo JR, Guerrero JM, Jimenez-Planas A, Sampedro C, Llamas R. EDTA inhibits in vitro substrate adherence capacity of macrophages: endodontic implications. J Endod 1997;23:205208.

8. Patterson SS. In vivo and in vitro studies of the effect of the disodium salt of ethylenediamine tetra-acetate on human dentine and its endodontic implications. Oral Surg Oral Med Oral Pathol 1963;16:83-103.

9. Busch L, Tessler J, Bazerque PM. Effects of calcium and EDTA on rat skin capillary permeability and on its response to histamine, serotonin and bradykinin. Acta Physiol Pharmacol Latinoamer 1989;39:227-234.

10. Lee HL, Cupples AL, Schubert RJ, Swartz ML. An adhesive dental restorative material. J Dent Res 1971;50:125-132.

11. Register AA, Burdick FA. Accelerated reattachment with cementogenesis to dentin, demineralized in situ. J Peridontol 1975;46:646-655.

12. Cotton WR, Siegel RL. Pulp response to citric acid cavity cleanser. US Navy J Med 1977;68:27-29.

13. Cole R, Nilveus R, Ainamo J, Bogle G, Crigger M, Egelberg J. Pilot clinical studies on the effect of topical citric acid application on healing after replaced periodontal flap surgery. J Periodont Res 1981;16:117-122.

14. Yamaguchi M, Yoshida K, Suzuki R, Nakamura H. Root canal irrigation with citric acid solution. J Endod 1996;22:27-29.

15. Sousa SMG, Bramante CM, Taga EM, Silva TL. Demineralizing efficiency of EGTA, EDTA and citric acid on dentin. J Dent Res 2000;79:347.

16. Siqueira Jr JF, Batista MMD, Fraga RC, Uzeda M. Antibacterial effects of endodontic irrigants on black-pigmented gram-negative anaerobes and facultative bacteria. J Endod 1998;24:414416. 
17. Udaka K, Takeuchi Y, Movat HZ. Simple method for quantitation of enhanced vascular permeability. Proc Soc Exper Biol Med 1970;133:1384-1387.

18. Catanzaro-Guimarães SA, Akatsu T, Taga EM, Consolaro A. Assessment of the antiexudative and antiproliferative activities of non-steroidal anti-inflammatory drugs in inflammatory models developed in rats by subcutaneous implantation of bacterial cell walls from the dental plaque. Inflammation 1996;20:623-636.
19. Nagem-Filho H, Pereira JC. Evaluation of the irritating potential of some intracanal medicaments in the exudative phase of inflammatory process. Rev Estomatol Cult 1976;10:1-6.

20. Dawson RMC, Elliott DC, Elliott WH, Jones KM. Carboxylic acids, alcohols, aldehydes, and ketones; $\mathrm{pH}$, buffers, and physiological media. In: Data for Biochemical Research. 3rd ed. Oxford, UK: Clarendon Press; 1986. p. 38-39; 427-428, 